\title{
A Review on coronavirus family persistency and considerations of novel type, covid-19 features
}

\author{
Armin Zarei $^{\text {(C) }}$ |Saeid Taghavi Fardood \\ aDepartment of Chemistry, University of Zanjan, \\ P.O. BOX 45195-313, Zanjan, Iran \\ ${ }^{b}$ Research Institute of Modern Biological \\ Techniques (RIMBT), P.O. BOX 45195-313, \\ University of Zanjan, Zanjan, Iran
}

The arrival of new types of viral diseases, namely coronavirus family, have posed a serious threat for global health. A new kind of coronavirus (CoV) named intense respiratory syndrome CoV2 (SARS-CoV-2 or COVID-19) firstly diagnosed in Huanan Seafood Wholesale, Wuhan City, China. The COVID-19 origination is likely to be from an animal host like bat and followed by person-person transmission unless the other routes possibility should be taken into account. The COVID-19 has been spread so fast all over the world, with more than 1,569,504 infected cases and 95,269 mortality as of April, $11^{\text {th }} 2020$, regardless of potent control and quarantine policy in more countries. Moreover, the SARS-CoV2 known as a novel coronavirus as it's initial genomic was less likely to be matched with the former CoV types. The human-human transmission range reported to be 2-14 days and its spread expansions would be comforted by surfaces, infected hands and droplets. This review focused on the persistency of different coronaviruses, like avain H7H9, SARS-CoV, MERS-CoV, Ebola virus and COVID19 , on varied surfaces as well as considering of COVID-19 features such as transmission, preventable policies, symptoms and suggested treatment ways to combat COVID-19.

\section{KEYWORDS}

Human-human transmission; pandemic; COVID-19.

\section{Introduction}

The hospitals of Wuhan, China, reported some novel and unknown pneumonia cases with unknown cause, in December 31, 2019, which have been considered as the most critical problem which human being has experienced over the last decades [1]. The Huanan Seafood Wholesale economic activities then ceased as the local public health suspected to its relation with the disease outbreak. Finally, researches figured out the arrival of a new type of coronavirus named SARS-CoV2 or COVID-19 by using next-generation sequencing as well as real-time reverse transcription polymerase chain reaction (RT-PCR) [2]. As the infected cases number in Wuhan was growly increasing because of holding a Chinese festival, public transport was first in Wuhan, and then in whole cities of Hubei province was suspended. The number of proved-PT-PCR cases has grown so fast that the World Health Organization (WHO) announced a pandemic in January 30, 2020. A new kind of coronavirus (SARS-CoV-2 or COVID-19) has diagnosed with a general increasing number of $1,569,564$ proved cases (as of April $8^{\text {th }}$, 2020) [3]. It could be asserted that this new type of $\mathrm{CoV}$ can be regarded as the third widely pathogenic coronavirus after SARS and MERS over the last 20 years [4]. Humanhuman transferring has been detected not only in family settings also in hospitals [3], so further spread in the public restriction should be put as the first criteria [5]. The hypothesis of coronaviruses transmission has been 
reported from polluted dry surfaces, including touching mucous membranes of nose, mouth, and eyes provides an opportunity to advance our understanding of coronavirus resistance on inanimate surfaces [6-8]. Recently, biocidal agents and disinfectants such as benzalkonium chloride, alcohols, hydrogen peroxide, and sodium hypochlorite, have been globally suggested for healthcare settings disinfection [9]. G. Kampf et al. reported the existed information of various types of coronaviruses, such as MERS-CoV, SARS-CoV, mouse hepatitis virus (MHV), transmissible gastroenteritis virus (TGEV) and canine coronavirus (CCV), persistency on varied insentient surfaces and classification of a variety of applied surface disinfectants against coronaviruses (Tables 1, 2, and 3) [10]. This research reviewed different coronaviruses persistency on varied surfaces and considering the essential features of COVID-19 such as persistency on variable surfaces, transmissions, preventable policies, symptoms and globally reported treatment ways for curing patients who suffer from COVID-19.

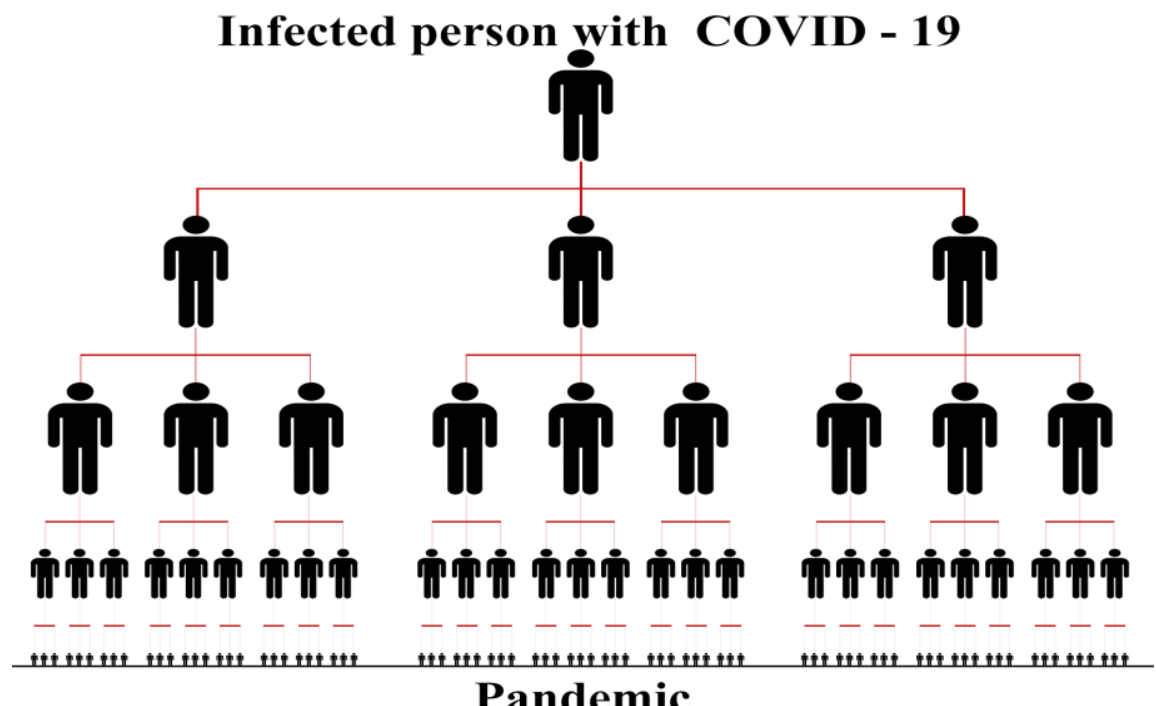

FIGURE 1 The schematic of COVID-19 and its turning into a pandemic

\section{Coronavirus persistency on intimate surfaces}

More information ascribed with the (HCoV-) $229 \mathrm{E}$ on a variable of surfaces and it could persist between $2 \mathrm{~h}$ and 9 days. Although, the TGEV and MHV persistency would increase up to 28 days at $40^{\circ} \mathrm{C}$, the pathogenic persistency of the mentioned two as well as MERS-CoV would be decreased at higher temperatures between $30{ }^{\circ} \mathrm{C}$ and $400{ }^{\circ} \mathrm{C}$. Lesser related information gained with SARS-CoV delineated a longer persistency with larger inoculum (Table 1). It was also found that, the $\mathrm{HCoV}$ $229 \mathrm{E}$ has a longer persistency of $50 \%$ in comparison with respective moisture of $30 \%$ at ambient temperature [11]. As for the persistence of COVID-19 on different surfaces, Neeltje van Doremalen et al. studied the aerosol and persistency of COVID-19 on a variable surfaces, such as copper, plastic, stainless steel and cardboard, and compared it with SARS-CoV. They reported that though persistency of two different coronaviruses was so similar to each other, COVID-19 could remain in the air about a couple of hours (up to $3 \mathrm{~h}$ ) and around 4 days on different surfaces (Table 1) [12]. 
TABLE 1 Comparing half-life and persistency of COVID-19 with SARS-CoV [12]

\begin{tabular}{ccccc}
\hline $\begin{array}{c}\text { Different } \\
\text { surfaces }\end{array}$ & $\begin{array}{c}\text { Anticipated } \\
\text { persistency of SARS- } \\
\text { CoV on varied surfaces }\end{array}$ & $\begin{array}{c}\text { Anticipated } \\
\text { persistency of } \\
\text { COVID-19 on } \\
\text { various surfaces }\end{array}$ & $\begin{array}{c}\text { Half life of } \\
\text { SARS-CoV on } \\
\text { various } \\
\text { surfaces }\end{array}$ & $\begin{array}{c}\text { Half life of } \\
\text { COVID-19 on } \\
\text { varied } \\
\text { surfaces }\end{array}$ \\
\hline $\begin{array}{c}\text { Copper } \\
\text { Cardboard }\end{array}$ & $<8$ hours & $<4$ hours & $\leq 2$ hours & 1 hour \\
Stainless steel & $<8$ hours & $<1$ day & $\leq 1$ hour & $\leq 5$ hours \\
Plastic & $\geq 2$ days & $\geq 2$ days & $\leq 5$ hours & 5.6 hours \\
Air & $\geq 3$ days & $\geq 3$ days & $\leq 9$ hours & 6.8 hours \\
\hline
\end{tabular}

TABLE 2 Coronaviruses persistency on varied surfaces (MHV: mouse hepatitis virus, HCoV: human coronavirus, SARS: Severe Acute Respiratory Syndrome; RT: ambient temperature, MERS: Middle East Respiratory Syndrome, TGEV: transmissible gastroenteritis virus)

\begin{tabular}{|c|c|c|c|c|c|c|}
\hline $\begin{array}{c}\text { Surface } \\
\text { type }\end{array}$ & Virus & Strain & $\begin{array}{l}\text { Inoculum } \\
\text { (viral titer) }\end{array}$ & Temperature & $\begin{array}{l}\text { Persistency } \\
\text { period }\end{array}$ & Ref. \\
\hline \multirow[t]{9}{*}{ Steel } & MHV & Unknown & $10^{6}$ & $4^{\circ} \mathrm{C}$ & $\geq 28 \mathrm{~d}$ & [13] \\
\hline & & & & $20^{\circ} \mathrm{C}$ & $4-28 d$ & \\
\hline & & & & $40^{\circ} \mathrm{C}$ & $4-96 \mathrm{~h}$ & \\
\hline & & Isolate & & & & \\
\hline & MERS-CoV & $\begin{array}{c}\text { HCoV- } \\
\text { EMC/2012 }\end{array}$ & $10^{5}$ & $20^{\circ} \mathrm{C}$ & $48 \mathrm{~d}$ & [14] \\
\hline & & & & $30^{\circ} \mathrm{C}$ & $8-24 \mathrm{~h}$ & \\
\hline & TGEV & Unknown & $10^{6}$ & $4^{\circ} \mathrm{C}$ & $\geq 28 \mathrm{~d}$ & [13] \\
\hline & & & & $20^{\circ} \mathrm{C}$ & $4-28 d$ & \\
\hline & & & & $40^{\circ} \mathrm{C}$ & $4-96 \mathrm{~h}$ & \\
\hline \multirow{4}{*}{$\begin{array}{c}\text { Ceramic } \\
\text { Silicon } \\
\text { rubber } \\
\text { Paper }\end{array}$} & $\mathrm{HCoV}$ & Strain 229E & $10^{3}$ & $21^{\circ} \mathrm{C}$ & $5 \mathrm{~d}$ & [15] \\
\hline & $\mathrm{HCoV}$ & Strain 229E & $10^{3}$ & $21^{\circ} \mathrm{C}$ & $5 \mathrm{~d}$ & [15] \\
\hline & SARS-CoV & Strain P9 & $10^{5}$ & AT & $4-5 d$ & [16] \\
\hline & SARS-CoV & $\begin{array}{c}\text { StrainGVU6 } \\
109\end{array}$ & $10^{6}$ & AT & $24 \mathrm{~h}$ & [17] \\
\hline $\begin{array}{l}\text { Surgical } \\
\text { glove }\end{array}$ & $\mathrm{HCoV}$ & $\begin{array}{l}\text { Strains } \\
\text { OC43 and } \\
229 \mathrm{E}\end{array}$ & $5 \times 10^{3}$ & $21^{\circ} \mathrm{C}$ & $\leq 8 \mathrm{~h}$ & [18] \\
\hline PVC & HCoV & Strain 229E & $10^{3}$ & $21^{\circ} \mathrm{C}$ & $5 \mathrm{~d}$ & [14] \\
\hline \multirow[t]{2}{*}{ Metal } & SARS-CoV & Strain P9 & $10^{5}$ & AT & $5 \mathrm{~d}$ & [16] \\
\hline & & $\begin{array}{c}\text { Strain P9 } \\
\text { Strains }\end{array}$ & $10^{5}$ & AT & $4-5 d$ & [16] \\
\hline Aluminum & $\mathrm{HCoV}$ & $\begin{array}{l}229 \mathrm{E} \text { and } \\
\text { OC43 }\end{array}$ & $5 \times 1^{03}$ & $21^{\circ} \mathrm{C}$ & $2-8 \mathrm{~h}$ & [19] \\
\hline Teflon & $\mathrm{HCoV}$ & Strain 229E & $10^{3}$ & $21^{\circ} \mathrm{C}$ & $5 \mathrm{~d}$ & [15] \\
\hline \multirow[t]{6}{*}{ Plastic } & SARS-CoV & $\begin{array}{l}\text { Strain FFM1 } \\
\text { Isolate }\end{array}$ & $10^{7}$ & $\mathrm{AT}$ & $6-9 d$ & [16] \\
\hline & MERS-CoV & $\begin{array}{c}\text { HCoV- } \\
\text { EMC/2012 }\end{array}$ & $10^{5}$ & $20^{\circ} \mathrm{C}$ & $48 \mathrm{~d}$ & [14] \\
\hline & & & & $30^{\circ} \mathrm{C}$ & & \\
\hline & $\mathrm{HCoV}$ & Strain 229E & $10^{7}$ & AT & $2-6 \mathrm{~d}$ & [16] \\
\hline & SARS-CoV & Strain P9 & $10^{5}$ & $\mathrm{AT}$ & $4 \mathrm{~d}$ & [20] \\
\hline & SARS-CoV & $\begin{array}{c}\text { Strain } \\
\text { HKU39849 }\end{array}$ & $10^{5}$ & $22-25{ }^{\circ} \mathrm{C}$ & $\leq 5 \mathrm{~d}$ & [16] \\
\hline \multirow{4}{*}{$\begin{array}{c}\text { Wood } \\
\text { Disposable } \\
\text { gown } \\
\text { Glass }\end{array}$} & SARS-CoV & Strain P9 & $10^{5}$ & $\mathrm{AT}$ & $4-5 \mathrm{~d}$ & [14] \\
\hline & SARS-CoV & $\begin{array}{c}\text { Strain } \\
\text { GVU6109 }\end{array}$ & $10^{6}$ & AT & $2 \mathrm{~d}$ & [17] \\
\hline & $\mathrm{HCoV}$ & Strain 229E & $10^{3}$ & $21^{\circ} \mathrm{C}$ & $5 \mathrm{~d}$ & [15] \\
\hline & SARS-CoV & Strain P9 & $10^{5}$ & AT & $4 \mathrm{~d}$ & [16] \\
\hline
\end{tabular}


TABLE 3 Varied types of inactivated coronaviruses using a variety of disinfectants (MERS: Middle East Respiratory Syndrome, CCV: canine coronavirus, HCoV: human coronavirus, MHV: mouse hepatitis virus, SARS: Severe Acute Respiratory Syndrome)

\begin{tabular}{|c|c|c|c|c|c|c|}
\hline Biocidal agent & $\begin{array}{l}\text { Concen } \\
\text { tration }\end{array}$ & Virus & Strain/isolate & $\begin{array}{l}\text { Exposure } \\
\text { time }\end{array}$ & $\begin{array}{c}\text { Decreasing } \\
\text { of viral } \\
\text { infectivity } \\
(\log 10)\end{array}$ & Ref. \\
\hline \multirow[t]{5}{*}{ 2-Propanol } & $50 \%$ & MHV & $\begin{array}{c}\text { Strains MHV-N and } \\
\text { MHV2 }\end{array}$ & $10 \mathrm{~min}$ & $\geq 3.7$ & [21] \\
\hline & $75 \%$ & MERS-CoV & Strain EMC & $30 \mathrm{~s}$ & $\geq 4.0$ & [22] \\
\hline & $70 \%$ & SARS-CoV & Isolate FFM-1 & $30 \mathrm{~s}$ & $\geq 3.3$ & [20] \\
\hline & $75 \%$ & SARS-CoV & Isolate FFM-1 & $30 \mathrm{~s}$ & $\geq 4.0$ & {$[22]$} \\
\hline & $100 \%$ & SARS-CoV & Isolate FFM-1 & $30 \mathrm{~s}$ & $\geq 3.3$ & [20] \\
\hline \multirow{4}{*}{$\begin{array}{c}\text { Sodium } \\
\text { hypochlorite }\end{array}$} & $0.21 \%$ & MHV & Strain MHV-1 & $30 \mathrm{~s}$ & $\geq 4.0$ & [23] \\
\hline & $0.01 \%$ & MHV & $\begin{array}{l}\text { Strain MHV-2 } \\
\text { Strain 1-71 }\end{array}$ & $10 \mathrm{~min}$ & $2.3-2.8$ & \\
\hline & $0.01 \%$ & CCV & $\begin{array}{l}\text { Strain } 1-/ 1 \\
\text { Strain MHV-2 }\end{array}$ & $10 \mathrm{~min}$ & 1.1 & [21] \\
\hline & $0.001 \%$ & MHV & and MHV-N & $10 \mathrm{~min}$ & $0.3-0.6$ & [21] \\
\hline \multirow{7}{*}{ Ethanol } & $\begin{array}{l}0.001 \% \\
70 \%\end{array}$ & $\begin{array}{l}\mathrm{CCV} \\
\mathrm{CCV}\end{array}$ & $\begin{array}{l}\text { Strain 1-71 } \\
\text { Strain 1-71 }\end{array}$ & $\begin{array}{l}10 \mathrm{~min} \\
10 \mathrm{~min}\end{array}$ & $\begin{array}{c}0.9 \\
\geq 5.5\end{array}$ & $\begin{array}{l}{[21]} \\
{[21]}\end{array}$ \\
\hline & $70 \%$ & MHV & $\begin{array}{c}\text { Strain MHV-N and } \\
\text { MHV-2 }\end{array}$ & $10 \mathrm{~min}$ & $\geq 5.5$ & {$[21]$} \\
\hline & $78 \%$ & SARS-CoV & Isolate FFM-1 & $30 \mathrm{~s}$ & $\geq 4.3$ & [20] \\
\hline & $80 \%$ & MERS-CoV & Strain EMC & $30 \mathrm{~s}$ & $\geq 4.0$ & [22] \\
\hline & $80 \%$ & SARS-CoV & Isolate FFM-1 & $30 \mathrm{~s}$ & $\geq 5.0$ & [24] \\
\hline & $95 \%$ & SARS-CoV & Isolate FFM-1 & $30 \mathrm{~s}$ & $>3.9$ & [24] \\
\hline & $85 \%$ & SARS-CoV & Isolate FFM-1 & $30 \mathrm{~s}$ & $>3.3$ & [24] \\
\hline \multirow[t]{4}{*}{$\begin{array}{l}\text { Benzalkonium } \\
\text { chloride }\end{array}$} & $0.05 \%$ & MHV & $\begin{array}{c}\text { Strain MHV-N and } \\
\text { MHV-2 }\end{array}$ & $10 \mathrm{~min}$ & 0.0 & [21] \\
\hline & $\begin{array}{c}0.00175 \\
\%\end{array}$ & CCV & Strain S378 & $3 d$ & $>3.7$ & [25] \\
\hline & $0.05 \%$ & $\mathrm{CCV}$ & Strain 1-71 & $10 \mathrm{~min}$ & $>3.7$ & [21] \\
\hline & $0.2 \%$ & $\mathrm{HCoV}$ & $\begin{array}{l}\text { ATCC VR-759 } \\
\text { (strain OC43) }\end{array}$ & $10 \mathrm{~min}$ & 3.0 & [26] \\
\hline \multirow[t]{5}{*}{ Formaldehyde } & $0.7 \%$ & MHV & & $10 \mathrm{~min}$ & $>3.0$ & {$[21]$} \\
\hline & $1 \%$ & SARS-CoV & Isolate FFM-1 & $2 \mathrm{~min}$ & $>3.0$ & [20] \\
\hline & $0.009 \%$ & CCV & & $24 \mathrm{~h}$ & $>3.5$ & [27] \\
\hline & $0.7 \%$ & SARS-CoV & Isolate FFM-1 & $2 \min$ & $>3.7$ & [20] \\
\hline & $0.7 \%$ & CCV & Strain 1-71 & $10 \mathrm{~min}$ & $>4.0$ & [21] \\
\hline $\begin{array}{l}\text { Hydrogen } \\
\text { peroxide }\end{array}$ & $0.5 \%$ & $\mathrm{HCoV}$ & Strain 229E & $1 \mathrm{~min}$ & $>4.0$ & [28] \\
\hline \multirow[t]{8}{*}{ Povidone-iodine } & $0.23 \%$ & MERS-CoV & $\begin{array}{l}\text { Isolate HCoV- } \\
\mathrm{EMC} / 2012\end{array}$ & $15 \mathrm{~s}$ & 4.6 & [29] \\
\hline & $0.25 \%$ & SARS-CoV & Hanoi strain & $1 \mathrm{~min}$ & 5.0 & [30] \\
\hline & $0.47 \%$ & SARS-CoV & Hanoi strain & $1 \mathrm{~min}$ & $>4.0$ & [30] \\
\hline & $1 \%$ & MERS-CoV & $\begin{array}{l}\text { Isolate HCoV- } \\
\text { EMC/2012 }\end{array}$ & $1 \mathrm{~min}$ & 4.3 & {$[31]$} \\
\hline & $4 \%$ & MERS-CoV & $\begin{array}{l}\text { Isolate HCoV- } \\
\text { EMC/2012 }\end{array}$ & $15 \mathrm{~s}$ & 3.8 & [31] \\
\hline & $\begin{array}{c}1 \% \\
0.23 \%\end{array}$ & $\begin{array}{l}\text { SARS-CoV } \\
\text { SARS-CoV }\end{array}$ & $\begin{array}{l}\text { Hanoi strain } \\
\text { Isolate FFM-1 }\end{array}$ & $\begin{array}{c}1 \mathrm{~min} \\
15 \mathrm{~s}\end{array}$ & $\begin{array}{l}>4.0 \\
>4.0\end{array}$ & $\begin{array}{l}{[30]} \\
{[29]}\end{array}$ \\
\hline & $7.5 \%$ & MERS-CoV & $\begin{array}{l}\text { Isolate HCoV- } \\
\text { EMC/2012 }\end{array}$ & $15 \mathrm{~s}$ & $>4.4$ & {$[31]$} \\
\hline & $0.23 \%$ & SARS-CoV & Hanoi strain & $1 \mathrm{~min}$ & $>4.4$ & [30] \\
\hline \multirow[t]{2}{*}{ Glutardialdehyde } & $2.5 \%$ & SARS-CoV & Hanoi strain & $5 \min$ & $>4.0$ & [30] \\
\hline & $0.5 \%$ & SARS-CoV & Isolate FFM-1 & $2 \min$ & $>4.0$ & [20] \\
\hline
\end{tabular}


Didecyldimethyl ammonium chloride

Chlorhexidine

digluconate

2-Propanol

1-propanol

Chlorhexidine digluconate

\subsection{5}

$\%$

$0.02 \%$

$45 \%$

$30 \%$

$0.02 \%$
CCV

MHV

SARS-CoV

SARS-CoV

MHV
Strain S378
Strains MHV-2 and
MHV-N
Isolate FFM-1
Isolate FFM-1
Strains MHV-2 and MHV-N

$\begin{array}{cc}3 \mathrm{~d} & >4.0 \\ & \\ 10 \mathrm{~min} & 0.7-0.8 \\ 30 \mathrm{~s} & \geq 4.3 \\ 30 \mathrm{~s} & \geq 2.8 \\ 10 \mathrm{~min} & 0.7-0.8\end{array}$

[25]

TABLE 4 Inactivation of coronaviruses by different types of biocidal agents in carrier tests (MHV: mouse hepatitis virus, $\mathrm{HCoV}$ : human coronavirus, TGEV: transmissible gastroenteritis virus)

\begin{tabular}{|c|c|c|c|c|c|c|c|c|}
\hline Biocidal agent & $\begin{array}{l}\text { Concentr } \\
\text { ation }\end{array}$ & Virus & Strain/isolate & Volume/material & $\begin{array}{c}\text { Organic } \\
\text { load }\end{array}$ & $\begin{array}{l}\text { Expos } \\
\text { ure } \\
\text { time }\end{array}$ & $\begin{array}{c}\text { Reducti } \\
\text { on of } \\
\text { viral } \\
\text { infectivi } \\
\text { ty } \\
(\log 10)\end{array}$ & Ref. \\
\hline $\begin{array}{l}\text { Benzalkonium } \\
\text { chloride }\end{array}$ & $0.04 \%$ & $\mathrm{HCoV}$ & Strain 229E & $\begin{array}{c}20 \mathrm{ml} / \text { stainless } \\
\text { steel }\end{array}$ & $\begin{array}{c}5 \% \\
\text { serum }\end{array}$ & $1 \mathrm{~min}$ & $<3.0$ & [32] \\
\hline $\begin{array}{c}\text { Hydrogen } \\
\text { peroxide }\end{array}$ & $\begin{array}{l}\text { Vapor of } \\
\text { unknown } \\
\text { concentra } \\
\text { tion }\end{array}$ & TGEV & $\begin{array}{l}\text { Purdue strain } \\
\text { type } 1\end{array}$ & $\begin{array}{c}20 \mathrm{ml} / \text { stainless } \\
\text { steel }\end{array}$ & None & $2-3 \mathrm{~h}$ & $4.9-5.3$ & [33] \\
\hline $\begin{array}{c}\text { Glutardialdeh } \\
\text { yde }\end{array}$ & $2 \%$ & $\mathrm{HCoV}$ & Strain 229E & $\begin{array}{c}20 \mathrm{ml} / \text { stainless } \\
\text { steel }\end{array}$ & $\begin{array}{c}5 \% \\
\text { serum }\end{array}$ & $1 \mathrm{~min}$ & $>3.0$ & {$[32]$} \\
\hline \multirow[t]{2}{*}{$\begin{array}{c}\text { Ortho- } \\
\text { phtalaldehyde }\end{array}$} & $0.55 \%$ & TGEV & Unknown & $\begin{array}{c}50 \mathrm{ml} / \text { stainless } \\
\text { steel }\end{array}$ & None & $1 \mathrm{~min}$ & 2.3 & [34] \\
\hline & $0.55 \%$ & MHV & Unknown & $\begin{array}{c}50 \mathrm{ml} / \text { stainless } \\
\text { steel }\end{array}$ & None & $1 \mathrm{~min}$ & 1.7 & {$[34]$} \\
\hline \multirow[t]{7}{*}{ Ethanol } & $71 \%$ & TGEV & Unknown & $\begin{array}{c}50 \mathrm{ml} / \text { stainless } \\
\text { steel }\end{array}$ & None & $1 \mathrm{~min}$ & 3.5 & [34] \\
\hline & $71 \%$ & MHV & Unknown & $\begin{array}{c}50 \mathrm{ml} / \text { stainless } \\
\text { steel }\end{array}$ & None & $1 \mathrm{~min}$ & 2.0 & [34] \\
\hline & $70 \%$ & TGEV & Unknown & $\begin{array}{c}50 \mathrm{ml} / \text { stainless } \\
\text { steel }\end{array}$ & None & $1 \mathrm{~min}$ & 3.2 & [34] \\
\hline & $70 \%$ & MHV & Unknown & $\begin{array}{c}50 \mathrm{ml} / \mathrm{stainless} \\
\text { steel }\end{array}$ & None & $1 \mathrm{~min}$ & 3.9 & {$[34]$} \\
\hline & $70 \%$ & $\mathrm{HCoV}$ & Strain 229E & $\begin{array}{c}20 \mathrm{ml} / \text { stainless } \\
\text { steel }\end{array}$ & $\begin{array}{c}5 \% \\
\text { serum }\end{array}$ & $1 \mathrm{~min}$ & $>3.0$ & [32] \\
\hline & $62 \%$ & TGEV & Unknown & $\begin{array}{c}50 \mathrm{ml} / \text { stainless } \\
\text { steel }\end{array}$ & None & $1 \mathrm{~min}$ & 4.0 & {$[34]$} \\
\hline & $62 \%$ & MHV & Unknown & $\begin{array}{c}50 \mathrm{ml} / \text { stainless } \\
\text { steel }\end{array}$ & None & $1 \mathrm{~min}$ & 2.7 & [34] \\
\hline \multirow[t]{4}{*}{$\begin{array}{c}\text { Sodium } \\
\text { hypochlorite }\end{array}$} & $0.5 \%$ & $\mathrm{HCoV}$ & Strain 229E & $\begin{array}{c}20 \mathrm{ml} / \text { stainless } \\
\text { steel }\end{array}$ & $\begin{array}{c}5 \% \\
\text { serum }\end{array}$ & $1 \mathrm{~min}$ & $>3.0$ & [32] \\
\hline & $0.1 \%$ & $\mathrm{HCoV}$ & Strain 229E & $\begin{array}{c}20 \mathrm{ml} / \text { stainless } \\
\text { stee }\end{array}$ & $\begin{array}{c}5 \% \\
\text { serum }\end{array}$ & $1 \mathrm{~min}$ & $>3.0$ & {$[32]$} \\
\hline & $0.06 \%$ & TGEV & Unknown & $\begin{array}{c}50 \mathrm{ml} / \text { stainless } \\
\text { steel }\end{array}$ & None & $1 \mathrm{~min}$ & 0.4 & [34] \\
\hline & $0.06 \%$ & MHV & Unknown & $\begin{array}{c}50 \mathrm{ml} / \text { stainless } \\
\text { steel }\end{array}$ & None & $1 \mathrm{~min}$ & 0.6 & [34] \\
\hline
\end{tabular}

Coronaviruses inactivation by different surfactants

As seen in Table 2, more trusted and applicable agents, such as 45\% 2-propanol with 30\% 1-propanol combination, ethanol
(78-95\%), 2-propanol (70-100\%), formaldehyde $\quad(0.7-1 \%)$, povidone-iodine (0.23-7.5\%), glutardialdehyde (0.5-2.5\%), have been reported by G.Kampf et al. They reported that, the range of inactivation infectious coronavirus was around $4 \log 10$ or 
more [10]. Approximately $0.21 \%$ of sodium hypochlorite proved to be sufficient. The $0.5 \%$ hydrogen peroxide with 1 min incubation time was also suitable. Information on benzalkonium chloride indicated a sensible contrast. Unless the concentration of $0.2 \%$ was less likely to be sufficient over $10 \mathrm{~min}$, the $0.05 \%$ concentration was sufficient over the same time against coronavirus. Finally, a $0.02 \%$ concentration of chlorhexidine digluconate had no efficacy.

Inactivation of coronaviruses by biocidal agents in carrier tests

Although different concentrations of ethanol, $62 \%$ and $71 \%$, were a suitable candidate for decreasing coronavirus infectious during just 1 min time of exposure by $0.2-0.4 \log 10$, $0.55 \%$ orthophtalaldehyde, benzalkonium chloride and $0.06 \%$ sodium hypochlorite revealed much less sufficiency against the virus. However, the concentrations of $2 \%$ glutardialdehyde and $0.1-0.5 \%$ sodium hypochlorite had great affectivity by 2.0-4.0 $\log 10$ (Table 3). G. Kampf et al. reported that, the infection durability of coronavirus, like SARS-CoV, around 9 days on a variety of solid surfaces. Surface decontamination using 62$71 \%$ ethanol and $0.1 \%$ sodium hypochlorite have a potential ability for the degradation of coronavirus infectivity on different surfaces for $1 \mathrm{~min}$, so it has been suggested to have a similar impact on SARS-CoV-2 [10].

\section{Transmission}

Recent studies have attempted to explain the zoonotic origin of COVID-19, so it is believed that initial infected people, who have been exposed to Seafood Wholesale Market in Wuhan City, might be come down with COVID19 by animals like bat and snake [35, 36]. Conducted researches on the COVID-19 genomic sequence showed an existed similarity up to $88 \%$ with known SARS coronavirus $[37,38]$. It has also been demonstrated that there had been a linkage between mammals, as the main COID-19 host, and humans. As for the further spread, humanhuman transmission is the most reasonable factor for COVID-19 infection. This claim has been proved by increasing detected cases within the families and among people who exposed of seafood market and those who did not visit it in Wuhan $[39,40]$. But how personperson transmission happen? It occurs in two different ways: firstly, by spreading droplets of sneezing or coughing an infected person in the environment, secondly, by direct contact of non-infected people with the infected individual. As for the aerosol transmission, prevent study focused on persistency of COVID-19 on variable surfaces, like copper, plastic, stainless steel and cardboard as well as in air, and made a comparison between COVID-19 and SARS-CoV. The researches figured out that fomite and aerosol transferring is possible as COVID-19 can persist in the air about a couple of hours (up to $3 \mathrm{~h}$ ) and around 4 days on different surfaces [12]. Moreover, mother to newborn transmission has not yet been reported due to the lack of trusted evidence. Although in recent study whole of studied pregnant women experienced cesarean sections, one question that needs to be asked, however, is whether transmission happened over natural birth. Therefore, susceptibility of pregnant females to COVID-19 infectivity by severe pneumonia is a crucial issue that should be taken into account [41]. Unless Qi Lu et al. reported the infectivity of 3 neonates and also 230 children aged below 18 with COVID-19 in January 2020, the disease condition was unlikely to be severe and no death has been detected in such age-group. Moreover, as there is no enough and reliable evidence for mother to infant transmission, more research should be fulfilled to give more information to neonatologists to control and treat the COVID19 [42]. Furthermore, though human to animals, such as pets, wildlife, and livestock, the transmission has not been yet approved by 
CDC and WHO, not enough document available to prove the fact that any pets are likely to get sick with COVID-19 and to be a cause of the further spread of viral infection. As there is no evidence to demonstrate such a transmission, protection criteria, such as washing hands whenever pets and their foods are touched, having a proper personal hygiene and take some advice from a veterinarian if there is needed questions about pets health, must be followed by people who are in touch with domestic animals [43]. As for the entrance of coronavirus into host cells, the host cells will express a receptor binding at the first step of viral infection and then it can be fused with membrane cell. Generally speaking, the main and initial target of the virus is the lung mucous cells, so person to person transferring of SARS-CoV happened when spikes of virus receptor-binding domain and a cell receptor named ACE2 (angiotensin-converting enzyme 2 ) would bind to each other [40,44]. Therefore, since receptor-binding domain CoVID-19 spikes have a high similarity to that of SARS-CoV, the COVID-19 is likely to enter into the host cells by the ACE2 receptor $[40,45]$.

\section{Preventable Policies}

To inhibit the further viral spread of COVID19 , international health organizations like WHO as well as CDC (US Centers for Disease Control and Prevention) have introduced some useful actions such as washing hands and follow recommended personal hygiene like continuous hand washing per a day as well as PPE usage like face masks and the use of alcoholic disinfectants, avoid meeting suspected people to COVID-19, do not use meat and eat foods in outdoors as they might make individual sick and unnecessary travel avoiding to places in which viral infectious have been reported [1, 46]. A Japanese company proceeded a symptom checker along with a humanmade intelligence-self-driven named Bebot which can show the updated information about the COVID-19 spread [47]. As for the other preventable policies, China and some European countries such as Spain and Italy have made rough house quarantine to inhibit the further spread of new coronavirus. Britain has also made some preventive measures like social distancing at least up to $1.5 \mathrm{~m}$, which was then followed by some countries including Iran, as well as house quarantine to some point.

\section{Symptoms}

It has clarified that the appearance of clinical properties of COVID-19, such as vomiting, myalgia, dry cough, fever and diarrhea [47], will take after incubation time up to 5.2 days [48]. Emergence of initial symptoms of COVID19 to death will take in a range of 6-41 days with an average period of 14 days [49]. The mentioned incubation period also is patient age dependent and it is related to the immune system of a patient. For example, the incubation time has been dedicated to be longer in the aged below 70 years compared to that of older people [49]. The other known symptoms of COVID-19 are dysponea, haemoptysis, headache, and lymphopenia [39, 49-51]. Although the clinical features have been proved by chest CT scan, abnormal properties like acute respiratory distress syndrome and acute cardiac injury detected [51]. The people who are suffering from previous diseases are more likely to be come down with a severe infection. Some important clinical properties of SARS compared to COVID-19 are presented in Table 5. Recently, catrin sohrabi et al. made a comparison between found information on vital epidemiological and clinical by CDC and WHO $[47,52]$ (Table 6). It is noteworthy saying that while the COVID-19 might have some same features, such as dyspnea, fever, dry cough, and ground-glass opacities [51], with the other coronaviruses, it delineates some unique clinical properties for example the lower airway is engaged with symptoms like 
sneezing, sore throat and rhinorrhea [53]. Furthermore, chest radiographs of some patients presented infiltration in the upper lung lobe due to increasing shortness of breath with hypoxemia [54]. COVID-19 sufferers revealed severe diarrhea whereas a low number of SARS-CoV and MERS-CoV patients experienced the mentioned symptom $[55,56]$, so it is undeniable that identification of different transmission modes, like urine samples and faecal test, has a high importance to find trusted minimization or inhibition transmission ways and to develop clinical trials to find a vaccine for control the disease. Table 7 presents a brief information of the studied clinical cases have collected by Jiang et al. [57].

TABLE 5 Comparing of SARS-CoV versus COVID-19. Data accurate as of $11^{\text {th }}$ April $[47,58,59]$

\begin{tabular}{ccc}
\hline & SARS-CoV & COVID-19 \\
\hline Clinical properties & Fever & Fever \\
& Cough & Cough \\
Total number of deaths globally & Shortness of breath & 95,269 \\
Number infected globally & 774 & $1,569,504$ \\
Incubation time & 8096 & $2-14$ days \\
Mortality & $2-7$ days & $3 \%$ \\
\hline
\end{tabular}

TABLE 6 Comparing of WHO diagnostic factors and CDC criteria based on travel and symptoms $[58,60]$

\begin{tabular}{|c|c|c|}
\hline & CDC & WHO \\
\hline $\begin{array}{c}\text { Epidemiological } \\
\text { Risk }\end{array}$ & $\begin{array}{l}\text { - Close contact with proved COVID-19 } \\
\text { patients during } 14 \text { days of initial } \\
\text { symptom onset } \\
\text { - Visited Hubei Province and traveled to } \\
\text { elsewhere } \\
\text { - Visited mainland China and traveled to } \\
\text { elsewhere }\end{array}$ & $\begin{array}{l}\text { - Healthcare staff who have exposed of } \\
\text { place where patients with ARI are being } \\
\text { cared for } \\
\text { - Unprecedented clinical course follows } \\
\text { regardless of treatment, including rapid } \\
\text { deterioration } \\
\text { - Present in healthcare facilities and } \\
\text { hospitals in countries where COVID-19 } \\
\text { has been reported } \\
\text { - Close contact (with distance of } 2 \\
\text { meters for over } 15 \text { minutes) with } \\
\text { confirmed COVID-19 infection } \\
\text { - Traveled from Hubei Province to } \\
\text { elsewhere } \\
\text { - All of the above can happen within } 14 \\
\text { days prior to symptom onset } \\
\text { - Cough } \\
\text { - Onset during the last } 10 \text { days } \\
\text { - Measured temperature } \geq 38 C^{\circ} \text { or fever } \\
\text { - Hospitalization needed } \\
\text { - Acute respiratory infection }\end{array}$ \\
\hline
\end{tabular}


TABLE 7 The summary of reported clinical studies

\begin{tabular}{|c|c|c|c|c|c|c|}
\hline Author & Wang et al. [46] & Song et al. [61] & Li et al. [48] & Chen et al. [52] & Huang et al. [62] & Chen et al. [63] \\
\hline Study setting & $\begin{array}{c}\text { Zhongnan } \\
\text { Hospital of } \\
\text { Wuhan } \\
\text { University } \\
\text { between Jan } 1 \\
\text { and Jan 28, } \\
\text { 2020, until Feb } \\
\text { 3, } 2020\end{array}$ & $\begin{array}{l}\text { Shanghai } \\
\text { Public } \\
\text { Health } \\
\text { Clinical } \\
\text { Center in the } \\
\text { time range of } \\
\text { Jan } 20 \text { to Jan } \\
27,2020\end{array}$ & $\begin{array}{c}\text { Some of } \\
\text { Hospitals in } \\
\text { Wuhan } \\
\text { on Jan 22, } 2020\end{array}$ & $\begin{array}{c}\text { Wuhan } \\
\text { Jinyintan } \\
\text { Hospital in the } \\
\text { time period of } \\
\text { Jan } 1 \text { to Jan 20, } \\
2020\end{array}$ & $\begin{array}{c}\text { Wuhan } \\
\text { Jinyintan } \\
\text { Hospital } \\
\text { between Dec } \\
\text { 16, } \\
2019 \text { and Jan 2, } \\
2020\end{array}$ & $\begin{array}{c}\text { Tongji Hospital } \\
\text { between Jan } \\
14 \text { and } \\
\text { Jan } 29,2020\end{array}$ \\
\hline City & $\begin{array}{l}\text { City of Wuhan, } \\
\text { China }\end{array}$ & $\begin{array}{l}\text { City of } \\
\text { Shanghai, } \\
\text { China }\end{array}$ & Wuhan, China & Wuhan, China & Wuhan, China & Wuhan, China \\
\hline $\begin{array}{l}\text { Total patients } \\
\text { Age, mean }\end{array}$ & 138 & 51 & 425 & 99 & 41 & 29 \\
\hline $\begin{array}{l}\text { (IQR) or mean } \\
\pm \text { SD, year }\end{array}$ & $56(42-68)$ & $49 \pm 16$ & $56(26-82)$ & $55.5 \pm 13.1$ & $49(41-58)$ & $56(26-79)$ \\
\hline Gender, male & $75(54.3 \%)$ & $25(49 \%)$ & $31(66 \%)$ & $67(68 \%)$ & $30(73 \%)$ & $21(72 \%)$ \\
\hline $\begin{array}{c}\text { Exposure } \\
\text { history, cases }\end{array}$ & $\begin{array}{c}12(8.7 \%) \\
\text { visited Seafood } \\
\text { Wholesale } \\
\text { Market Haunan }\end{array}$ & $\begin{array}{c}50(98 \%) \text { Met } \\
\text { Wuhan }\end{array}$ & $\begin{array}{c}26(55 \%) \\
\text { visited Seafood } \\
\text { Wholesale } \\
\text { Market Haunan }\end{array}$ & $\begin{array}{l}9 \text { (49\%) Visited } \\
\text { Seafood } \\
\text { Wholesale } \\
\text { Market Haunan }\end{array}$ & $\begin{array}{c}27(66 \%) \text { met } \\
\text { Seafood } \\
\text { Wholesale } \\
\text { Market Haunan }\end{array}$ & $\begin{array}{l}2(7 \%) \\
\text { exposed to } \\
\text { Huanan } \\
\text { Seafood } \\
\text { Wholesale } \\
\text { Market }\end{array}$ \\
\hline $\begin{array}{c}\text { CT } \\
\text { findings, } X- \\
\text { ray and cases }\end{array}$ & $\begin{array}{c}\text { Ground glass } \\
\text { opacity138 } \\
(100 \%)\end{array}$ & $\begin{array}{c}\text { Ground glass } \\
\text { opacity, } \\
39(77 \%)\end{array}$ & $\begin{array}{l}\text { Radiographic } \\
\text { revealed } \\
\text { symptoms of } \\
\text { pneumonia }\end{array}$ & $\begin{array}{c}\text { Multiple } \\
\text { mottling and } \\
\text { ground glass } \\
\text { opacity, } \\
14(14 \%)\end{array}$ & $\begin{array}{c}\text { Bilateral } \\
\text { ground } \\
\text { glass opacity, } \\
40 \\
(98 \%)\end{array}$ & NU \\
\hline $\begin{array}{l}\text { Signs and } \\
\text { symptoms }\end{array}$ & $\begin{array}{c}\text { Headache, } 9 \\
(6.5 \%) \\
\text { Diarrhea, } 14 \\
(10.1 \%) \\
\text { Dizziness, } 13 \\
(9.4 \%) \\
\text { Abdominal pain, } \\
3(2.2 \%) \\
\text { Myalgia, 48 } \\
(34.8 \%) \\
\text { Headache, } 9 \\
(6.5 \%) \\
\text { Nausea, } 14 \\
(10.1 \%) \\
\text { Dry cough, } 82 \\
(59.4 \%) \\
\text { Anorexia, } 55 \\
(39.9 \%) \\
\text { Fatigue, } 96 \\
(69.6 \%) \\
\text { Dyspnea, } 43 \\
(31.2 \%) \\
\text { Expectoration, } \\
37 \text { (26.8\%) } \\
\text { Pharyngalgia, } 24 \\
(17.4 \%) \\
\text { Fever, } 136 \\
\text { (98.6\%) } \\
\text { Vomiting, } 5 \\
(3.6 \%)\end{array}$ & $\begin{array}{c}\text { Pain, } 7(14 \%) \\
\text { Headache and } \\
\text { dizziness, } 8 \\
(16 \%) \\
\text { Loss of } \\
\text { appetite, } \\
9(18 \%) \\
\text { Diarrhea 5, } \\
(10 \%) \\
\text { Stuffy and } \\
\text { runny } \\
\text { nose, } 2(4 \%) \\
\text { Sore throat, } 3 \\
\text { (6\%) } \\
\text { Nausea and } \\
\text { Dyspnea or } \\
\text { chest } \\
\text { vomiting, } 3 \\
(6 \%) \\
\text { Fever, } 49 \\
(96 \%) \\
\text { Cough, } 24 \\
(47 \%) \\
\text { Phlegm, } 10 \\
(20 \%) \\
\text { Myalgia or } \\
\text { fatigue, } \\
16(31 \%) \\
\text { Dyspnea or } \\
\text { chest }\end{array}$ & $\begin{array}{l}\text { Fever, with or } \\
\text { without } \\
\text { recorded } \\
\text { temperature }\end{array}$ & $\begin{array}{c}\text { Chest pain, } 2 \\
(2 \%) \\
\text { Diarrhea, } 2 \\
(2 \%) \\
\text { Nausea and } \\
\text { vomiting, } \\
1(1 \%) \\
\text { Fever, } 82(83 \%) \\
\text { Rhinorrhea, } 4 \\
(4 \%) \\
\text { Cough, } 81 \\
(82 \%) \\
\text { Shortness of } \\
\text { breath, 31 } \\
(31 \%) \\
\text { Muscle ache, } 11 \\
(11 \%) \\
\text { Confusion, } 9 \\
(9 \%) \\
\text { Headache, } 8 \\
(8 \%) \text { Sore } \\
\text { throat, } 5(5 \%)\end{array}$ & $\begin{array}{c}\text { Sputum } \\
\text { production, } \\
11 / 39(28 \%) \\
\text { Fever, 40 } \\
(98 \%) \\
\text { Hemoptysis, } \\
2 / 39(5 \%) \\
\text { Cough, } 31 \\
(76 \%) \\
\text { Diarrhea, } 1 / 38 \\
(3 \%) \\
\text { Dyspnea, } 22 / 40 \\
\text { (55\%) Myalgia } \\
\text { or fatigue, } \\
18(44 \%) \\
\text { Headache, 3/38 } \\
(8 \%)\end{array}$ & $\begin{array}{c}\text { Dyspnea, } 17 \\
\text { (59\%) } \\
\text { Fever, } 28 \\
(97 \%) \\
\text { Myalgia or } \\
\text { fatigue, } \\
12(41 \%) \\
\text { Diarrhea, } 4 \\
(14 \%) \\
\text { Cough or } \\
\text { expectoration, } \\
21 \\
(72 \%) \\
\text { Headache, } 2 \\
\text { (7\%) }\end{array}$ \\
\hline Complications & $\begin{array}{c}\text { AKI,10 (7.2\%) } \\
\text { Arrhythmia, } 23 \\
(16.7 \%) \\
\text { ARDS, } 27 \\
(19.6 \%) \\
\text { Shock, } 12 \\
(8.7 \%)\end{array}$ & $\mathrm{NU}$ & NU & $\begin{array}{c}\text { ARDS, } 17(17 \%) \\
\text { Acute } \\
\text { respiratory } \\
\text { injury, } 8(8 \%) \\
\text { Septic shock, } 4 \\
(4 \%) \\
\text { ARI, } 3(3 \%) \\
\text { Ventilator- } \\
\text { associated } \\
\text { pneumonia, } 1 \\
(1 \%)\end{array}$ & $\begin{array}{c}\text { RNAemia, } 6 \\
(15 \%) \\
\text { Secondary } \\
\text { infection, } 4 \\
(10 \%) \\
\text { AKI, } 3(7 \%) \\
\text { RDS, } 12(29 \%) \\
\text { Acute cardiac } \\
\text { injury, } 5(12 \%) \\
\text { Secondary } \\
\text { infection, } 4\end{array}$ & $\mathrm{NU}$ \\
\hline
\end{tabular}




\begin{tabular}{|c|c|c|c|c|c|}
\hline Treatments & $\begin{array}{c}\text { Antiviral, } 124 \\
(89.9 \%) \\
\text { ECMO, } 4(2.9 \%) \\
\text { Glucocorticoid, } \\
62(44.9 \%) \\
\text { IMV, } 17 \\
(12.32 \%) \\
\text { CRRT, } 2(1.45 \%) \\
\text { Oxygen } \\
\text { inhalation, } \\
106(76.81 \%) \\
\text { NIV, } 15(10.9 \%)\end{array}$ & $\mathrm{NU}$ & $\mathrm{NU}$ & $\begin{array}{c}\text { CRRT, } 9(9 \%) \\
\text { ECMO, } 3(3 \%) \\
\text { Oxygen therapy, } \\
75(76 \%) \\
\text { NIV, } 13 \\
(13 \%) \\
\text { IMV, } 4(4 \%) \\
\text { Antifungal, } 15 \\
(15 \%) \\
\text { Antiviral, } 75 \\
(76 \%) \\
\text { Glucocorticoids, } \\
19 \\
(19 \%)\end{array}$ & $\begin{array}{c}\text { Nasal cannula, } \\
27(66 \%) \\
\text { NIV } \\
\text { or high-flow } \\
\text { nasal } \\
\text { cannula, } 10 \\
(24 \%) \\
\text { Antiviral, } 38 \\
(93 \%) \\
\text { Antibiotic, } 41 \\
(100 \%) \\
\text { Corticosteroid, } \\
9(22 \%) \\
\text { CRRT, } 3(7 \%) \\
\text { IMV, } 2(5 \%)\end{array}$ \\
\hline
\end{tabular}

AKI acute kidney injury, ECMO extracorporeal membrane oxygenation, ARDS acute respiratory syndrome distress, IMV invasive mechanical ventilation, NIV noninvasive ventilation, NA not useful, CRRT continuous renal replacement therapy, ARI acute renal injury

TABLE 8 Coronavirus cases: discharged and death

\begin{tabular}{ccccccc}
\hline Author & $\begin{array}{c}\text { Wang et al. } \\
\text { [46] }\end{array}$ & $\begin{array}{c}\text { Song et al. } \\
\text { [61] }\end{array}$ & $\begin{array}{c}\text { Chen et al. } \\
{[\text { [52] }}\end{array}$ & Chen et al. [63] & $\begin{array}{c}\text { Li et al. } \\
\text { [48] }\end{array}$ & $\begin{array}{c}\text { Huang et } \\
\text { al. [62] }\end{array}$ \\
\hline & & & & Immunoglobulin, & & $\begin{array}{c}\text { ECMO and } \\
\text { IMV }\end{array}$ \\
& & & & $27(27 \%)$ & & $2(5 \%)$ \\
Discharged & $47(34.1 \%)$ & $\mathrm{NU}$ & $\mathrm{NU}$ & $31(31 \%)$ & $\mathrm{NU}$ & $28(68 \%)$ \\
Death & $6(4.3 \%)$ & $\mathrm{NU}$ & $2(7 \%)$ & $11(11 \%)$ & $\mathrm{NU}$ & $6(15 \%)$ \\
\hline
\end{tabular}

\section{Treatment}

Although little is known about the treatment of COVID-19 and yet there is no proved vaccine to treat the COVID-19, some randomized clinical trials are recently going to be accomplished to find a highly sufficient vaccine to cure patients who have come down with COVID-19. The initial used treatment for fevers is to use the paracetamol and guaifenesin for coughing [46]. Oxygen therapy administration usage has recently reported for patients who have symptoms such as hypoxemia, shock, severe acute respiratory infection and respiratory distress. This could be done at $5 \mathrm{~L} / \mathrm{min}$ to gain $\geq 92-95 \% \mathrm{SpO} 2$ targets in pregnant women, and $\geq 90 \%$ in the others [64-66]. The intravenous fluids prescription ought to be prioritized for patients with no shock symptoms [67]. Moreover, if the AKI (Acute kidney injury) observed, renal replacement therapy (RRT) would be required. Fluid balance along with renal function might be suitable identification tools for patients who are RRT needed [46]. A wide range of antibiotics has been suggested to be used over the first $1 \mathrm{~h}$ of sepsis assessment [68]. The emergence of further fungal and bacterial infections in patients should be taken into account during the middle stage of the disease, so rational and conservative antibiotic regimens using are necessitated [69]. As previous studies on SARS-CoV indicated a meaningful decrease in the rates of mortality infected patients with SARS by prescription of lopinavir/ritonavir and IFN- $\alpha$, their usage has been suggested by the Chinese National Health Commission [70]. Unless the unclear affectivity of oseltamivir, an approval antiviral medicine prescribed for the influenza A and influenza B treatment, on COVID-19, it is used for suspected infections in Chinese hospitals. If the patients also had severe immune symptoms, then glucocorticoids would be used. Limited usage of methylprednisolone in children has been 
recommended to be $1-2 \mathrm{mg} / \mathrm{kg} /$ day for a 5 day-period [46,71]. In the other study, W.Zhong et al. demonstrated the efficacy of favipiravir on COVID-19 and made a comparison between it and lopinavir as well as ritonavir. Interestingly, there was a shorter viral improvement time compared to that of the other used drugs, with the range of 2.5-9 days (average of 4 days) and 8-13 days with an average of 11 days. As for chest imaging clearance, FVP also revealed to be a better candidate with more than $91 \%$ improvement compared to $62.2 \%$ caused clearance by ritonavir and lopinavir. They finally mentioned that favipiravir could be a suitable treatment tool for COVID-19 infection [72]. Xinghuan Wang et al. also conducted comparative research between two drug usages like favipiravir and arbidol for 120 infected patients with SARS-CoV2 to figure out the highly efficient antiviral drug to combat COVID-19. Their findings revealed that favipiravir is likely to be preferable antiviral drug, due to its supreme clinical improvement over a week with an average clinical improvement rate of $71.43 \%$ compared to the lower rate of $55 \%$ of arbidol, favipiravir can also make a considerable decrease in fever incidence and cough, over the arbidol [73]. A recent study proposed some approval FDA drugs such as chloroquine, nafamostat, penciclovir, nitazoxanide, and two familiar antiviral medicines named favipiravir and remdisivir versus isolated COVID-19 in vitro. Although ribavirin, favipiravir and penciclovir approved to be useful in infection decrease, favipiravir released $100 \%$ protection efficacy in mice in vero E6 cells, and however, more studies are needed to make its real antiviral potential clear. As for nafamostat and nitazoxanide antiviral affectivity, the findings showed a good capability to some point unless chloroquine and remdisivir have a high ability to block viral infection [74]. It was reported that, the ACE2 is the known receptor for SARSCoV2 infections. Also, it has been suggested that if the interaction between the mentioned receptor and COVID-19 spikes is blocked, it will be a possible treat for the COVID-19. Though no evidence yet exited to prove the fact that if hrsACE2, human recombinant soluble ACE2, can COVID-19 growth blockage, Josef $\mathrm{M}$ Penninger et al. dedicated that hrsACE2 capability to decrease COVID-19 growth in Vero cells between a factor of 1,000 and 5,000 and its ability to make a sustainable blockage in initial steps of SARS-CoV2 infectivity, so they proposed that it might be an applicable tool for SARS-CoV2 treatment. The researchers also mentioned that COVID19 is more likely to be responsible for kidney and blood vessel organoids [45].

\section{Conclusion}

The international deadly and new viral infection named COVID-19 or SARS-CoV has been spread throughout the world and it has been turned into a pandemic. The number of dedicated COVID-19 cases is continuously increasing; and it placed at 1,569,564 confirmed cases with 95,269 reported deaths. It is believed that prevention policies like quarantine are less likely to be sufficient to prohibit and full control of the disease. The exact mechanism of animal to human as well as human to animal transferring should be estimated as it has high importance to find an antiviral drug to treat COVID-19. As is undeniable that COVID-19 possesses a large pandemic potential, careful monitoring and strict surveillance are strongly required because the mentioned two factors can significantly decrease the mortality rates and prevent the further prevalence of the disease. More news and daily information about the COVID-19 presents the fast changing of the virus nature, so it which will restrict a general overview of the COVID-19 and its unknown features. The WHO and international healthcare societies have to be aware of the mentioned symptoms and signs and diagnose new suspected cases to be able to control the further viral spread. 


\section{Acknowledgements}

The authors would like to appreciate the University of Zanjan for its support.

\section{Orcid:}

Armin Zarei: https://orcid.org/0000-00030761-1085

Saeid Taghavi Fardood:

https://orcid.org/0000-0002-0645-1393

Farzaneh Moradnia: https://orcid.org/00000001-8595-9808

Ali Ramazani: https://orcid.org/0000-00033072-7924

\section{References}

[1] C. Wang, P.W. Horby, F.G. Hayden, G.F. Gao, Lancet, 2020, 395, 470-473.

[2] N. Zhu, D. Zhang, W. Wang, X. Li, B. Yang, J. Song, X. Zhao, B. Huang, W. Shi,R. Lu, New Engl. J. Med., 2020, 382, 727-733.

[3] K. Dhama, K. Sharun, R. Tiwari, S. Sircar, S. Bhat, Y.S. Malik, K.P. Singh, W. Chaicumpa, D.K. Bonilla-Aldana, A.J. Rodriguez-Morales, Preprints, 2020, 2020030001, 1-75.

[4] E. de Wit, N. van Doremalen, D. Falzarano,V.J. Munster, Nat. Rev. Microbiol., 2016, 14, 523.

[5] J.F.-W. Chan, S. Yuan, K.-H. Kok, K.K.-W. To, H. Chu, J. Yang, F. Xing, J. Liu, C.C.-Y. Yip, R.W.S. Poon, Lancet, 2020, 395, 514-523.

[6] J. Otter, C. Donskey, S. Yezli, S. Douthwaite, S. Goldenberg, D. Weber, J. Hosp. Infect., 2016, 92, 235-250.

[7] S.F. Dowell, J.M. Simmerman, D.D. Erdman, J.-S.J. Wu, A. Chaovavanich, M. Javadi, J.-Y. Yang, L.J. Anderson, S. Tong, M.S. Ho, Clin. Infect. Dis., 2004, 39, 652-657.

[8] C. Geller, M. Varbanov, R.E. Duval, Viruses, 2012, 4, 3044-3068.

[9] G. Kampf, Antiseptic stewardship, Springer, 2018.

[10] G. Kampf, D. Todt, S. Pfaender, E. Steinmann, J. Hosp. Infect., 2020, 104, 246251.

[11] M. Ijaz, A. Brunner, S. Sattar, R.C. Nair, C. Johnson-Lussenburg, J. Gen. Virol., 1985, 66, 2743-2748.

[12] N. van Doremalen, T. Bushmaker, D.H. Morris, M.G. Holbrook, A. Gamble, B.N. Williamson, A. Tamin, J.L. Harcourt, N.J.
Thornburg, S.I. Gerber, New Engl. J. Med., 2020, 382, 1564-1567.

[13] L.M. Casanova, S. Jeon, W.A. Rutala, D.J. Weber, M.D. Sobsey, Appl. Environ. Microbiol., 2010, 76, 2712-2717.

[14] N. Van Doremalen, T. Bushmaker,V. Munster, Euro Surveill., 2013, 18, 20590.

[15] S.L. Warnes, Z.R. Little, C.W. Keevil, MBio, 2015, 6, e01697-01615.

[16] S. Duan, X. Zhao, R. Wen, J.-j. Huang, G. Pi, S. Zhang, J. Han, S. Bi, L. Ruan,X.-p. Dong, Biomed. Environ. Sci., 2003, 16, 246.

[17] M.Y. Lai, P.K. Cheng,W.W. Lim, Clin. Infect. Dis., 2005, 41, e67-e71.

[18] N.J. Emery, A.M. Seed, A.M.P. von Bayern, N.S. Clayton, Philos. Trans. R. Soc. Lond. B Biol. Sci., 2007, 362, 489-505.

[19] J. Sizun, M. Yu, P. Talbot, J. Hosp. Infect., 2000, 46, 55-60.

[20] H. Rabenau, J. Cinatl, B. Morgenstern, G. Bauer, W. Preiser, H. Doerr, Med. Microbiol. Immunol., 2005, 194, 1-6.

[21] M. SAKNIMIT, I. INATSUKI, Y. SUGIYAMA,K.-i. YAGAMI, Exp. Anim., 1988, 37, 341-345.

[22] A. Siddharta, S. Pfaender, N.J. Vielle, R. Dijkman, M. Friesland, B. Becker, J. Yang, M. Engelmann, D. Todt, M.P. Windisch, J. Infect. Dis., 2017, 215, 902-906.

[23] C. Dellanno, Q. Vega, D. Boesenberg, Am. J. Infect. Control, 2009, 37, 649-652.

[24] H. Rabenau, G. Kampf, J. Cinatl,H. Doerr, J. Hosp. Infect., 2005, 61, 107-111.

[25] A. Pratelli, Zoonoses and Public Health, 2007, 54, 383-386.

[26] A. Wood, D. Payne, J. Hosp. Infect., 1998, 38, 283-295.

[27] A. Pratelli, The Veterinary Journal, 2008, 177, 71-79.

[28] N. Omidbakhsh, S.A. Sattar, Am. J. Infect. Control, 2006, 34, 251-257.

[29] M. Eggers, T. Koburger-Janssen, M. Eickmann,J. Zorn, Infect. Dis. Ther., 2018, 7, 249-259.

[30] H. Kariwa, N. Fujii,I. Takashima, Dermatology, 2006, 212, 119-123.

[31] M. Eggers, M. Eickmann, J. Zorn, Infect. Dis. Ther., 2015, 4, 491-501.

[32] S. Sattar, V. Springthorpe, Y. Karim, P. Loro, Epidemiol. Infect., 1989, 102, 493-505.

[33] S.M. Goyal, Y. Chander, S. Yezli, J. Otter, J. Hosp. Infect., 2014, 86, 255-259. 
[34] R.L. Hulkower, L.M. Casanova, W.A. Rutala, D.J. Weber, M.D. Sobsey, Am. J. Infect. Control, 2011, 39, 401-407.

[35] M. Bassetti, A. Vena, D.R. Giacobbe, Eur. J. Clin. Invest., 2020, 50, e13209.

[36] W. Ji, W. Wang, X. Zhao, J. Zai, X. Li, J. Med. Virol., 2020, 92, 433-440.

[37] R. Lu, X. Zhao, J. Li, P. Niu, B. Yang, H. Wu, W. Wang, H. Song, B. Huang, N. Zhu, Lancet, 2020, 395, 565-574.

[38] Y. Wan, J. Shang, R. Graham, R.S. Baric, F. Li, J. Virol., 2020, 94.

[39] W.G. Carlos, C.S. Dela Cruz, B. Cao, S. Pasnick, S. Jamil, Am. J. Respir. Crit. Care Med., 2020, 201, P7-P8.

[40] P. Wu, X. Hao, E.H. Lau, J.Y. Wong, K.S. Leung, J.T. Wu, B.J. Cowling, G.M. Leung, Euro Surveill., 2020, 25.

[41] D.A. Schwartz, Arch. Pathol. Lab. Med., 2020, doi: 10.5858/arpa.2020-0901-SA

[42] Q. Lu, Y. Shi, J. Med. Virol., 2020, 92, 564567.

[43] D.R. Murdoch, N.P. French, N.Z. Med. J., 2020, 133, 12-15.

[44] J.A. Jaimes, J.K. Millet, A.E. Stout, N.M. André, G.R. Whittaker, Viruses, 2020, 12, 83.

[45] V. Monteil, H. Kwon, P. Prado, A. Hagelkrüys, R.A. Wimmer, M. Stahl, A. Leopoldi, E. Garreta, C.H. del Pozo,F. Prosper, Cell, 2020, doi: 10.1016/i.cell.2020.04.004

[46] Y. Bai, L. Yao, T. Wei, F. Tian, D.-Y. Jin, L. Chen,M. Wang, Jama, 2020, 323, 1406-1407.

[47] C. Sohrabi, Z. Alsafi, N. O’Neill, M. Khan, A. Kerwan, A. Al-Jabir, C. Iosifidis, R. Agha, Int. J. Surg., 2020, 76, 71-76.

[48] R. Thompson, Lancet Infect. Dis., 2020, 20, 280.

[49] W. Wang, J. Tang, F. Wei, J. Med. Virol., 2020, 92, 441-447.

[50] L.-L. Ren, Y.-M. Wang, Z.-Q. Wu, Z.-C. Xiang, L. Guo, T. Xu, Y.-Z. Jiang, Y. Xiong, Y.-J. Li,H. Li, Chin. Med. J., 2020, doi: 10.1097/CM9.0000000000000722

[51] C. Huang, Y. Wang, X. Li, L. Ren, J. Zhao, Y. $\mathrm{Hu}$, L. Zhang, G. Fan, J. Xu, X. Gu, Lancet, 2020, 395, 497-506.

[52] N. Chen, M. Zhou, X. Dong, J. Qu, F. Gong, Y. Han, Y. Qiu, J. Wang, Y. Liu, Y. Wei, J.a. Xia, T. Yu, X. Zhang, L. Zhang, Lancet, 2020, 395, 507-513. [53] H.A. Rothan, S.N. Byrareddy, J. Autoimmun., 2020, 109, 102433.

[54] L.T. Phan, T.V. Nguyen, Q.C. Luong, T.V. Nguyen, H.T. Nguyen, H.Q. Le, T.T. Nguyen,
T.M. Cao,Q.D. Pham, New Engl. J. Med., 2020, 382, 872-874.

[55] A. Assiri, J.A. Al-Tawfiq, A.A. Al-Rabeeah, F.A. Al-Rabiah, S. Al-Hajjar, A. Al-Barrak, H. Flemban, W.N. Al-Nassir, H.H. Balkhy, R.F. AlHakeem, Lancet Infect. Dis., 2013, 13, 752-761. [56] N. Lee, D. Hui, A. Wu, P. Chan, P. Cameron, G.M. Joynt, A. Ahuja, M.Y. Yung, C. Leung, K. To, New Engl. J. Med., 2003, 348, 1986-1994.

[57] F. Jiang, L. Deng, L. Zhang, Y. Cai, C.W. Cheung, Z. Xia, J. Gen. Intern. Med., 2020, DOI: 10.1007/s11606-020-05762-w.

[58] B. Amber Ather, B. Nikita, J. Endod., 2020, 46, 584-595.

[59] D.S.C. HUI, P.C. WONG,C. Wang, Respirology, 2003, 8, S20-S24.

[60] W.H. Organization, Clinical management of severe acute respiratory infection when novel coronavirus ( $n \mathrm{CoV})$ infection is suspected: interim guidance, 25 January 2020, World Health Organization, 2020.

[61] F. Song, N. Shi, F. Shan, Z. Zhang, J. Shen, H. Lu, Y. Ling, Y. Jiang, Y. Shi, Radiology, 2020, 295, 200274.

[62] V.M. Corman, O. Landt, M. Kaiser, R. Molenkamp, A. Meijer, D.K. Chu, T. Bleicker, S. Brünink, J. Schneider, M.L. Schmidt, Euro Surveill., 2020, 25.

[63] H. Li, C. Lan, H. Weng, S. Chen, Q. Lin,J. Huang, Chin. J. Tuberc. Respir. Dis., 2017, 40, 850-854.

[64] W.H. Organization, Clinical management of severe acute respiratory infection when novel coronavirus ( 2019-nCoV) infection is suspected: interim guidance, 28 January 2020, World Health Organization, 2020.

[65] H. Røsjø, M. Varpula, T.-A. Hagve, S. Karlsson, E. Ruokonen, V. Pettilä, T. Omland, F.S. Group, Intensive Care Med., 2011, 37, 7785.

[66] W.H. Organization, Pocket book of hospital care for children: guidelines for the management of common childhood illnesses, World Health Organization, 2013.

[67] W.H. Organization, WHO Global Epidemiological Surveillance Standards for Influenza, Geneva, 2014.

[68] M.J. Schultz, M.W. Dunser, A.M. Dondorp, N.K. Adhikari, S. Iyer, A. Kwizera, Y. Lubell, A. Papali, L. Pisani, B.D. Riviello, Intensive Care Med., 2017, 43, 612-624.

[69] A. Rhodes, L.E. Evans, W. Alhazzani, M.M. Levy, M. Antonelli, R. Ferrer, A. Kumar, J.E. 
Sevransky, C.L. Sprung, M.E. Nunnally, Intensive Care Med., 2017, 43, 304-377.

[70] C. Chu, V. Cheng, I. Hung, M. Wong, K. Chan, K. Chan, R. Kao, L. Poon, C. Wong,Y. Guan, Thorax, 2004, 59, 252-256.

[71] L. Kui, Y.-Y. Fang, Y. Deng, W. Liu, M.-F. Wang, J.-P. Ma, W. Xiao, Y.-N. Wang, M.-H. Zhong, C.-H. Li, Chin. Med. J., 2020, doi: 10.1097/CM9.0000000000000744

[72] Q. Cai, M. Yang, D. Liu, J. Chen, D. Shu, J. Xia, X. Liao, Y. Gu, Q. Cai,Y. Yang, Engineering, 2020, doi: $10.1016 /$ i.eng.2020.03.007

[73] C. Chen, J. Huang, Z. Cheng, J. Wu, S. Chen, Y. Zhang, B. Chen, M. Lu, Y. Luo, J. Zhang, medRxiv, 2020, doi: $\underline{10.1101 / 2020.03 .17 .20037432}$
[74] M. Wang, R. Cao, L. Zhang, X. Yang, J. Liu, M. Xu, Z. Shi, Z. Hu, W. Zhong, G. Xiao, Cell Res., 2020, 30, 269-271.

How to cite this article: Armin Zarei. Saeid Taghavi Fardood*, Farzaneh Moradnia, Ali Ramazani*, A Review on coronavirus family persistency and considerations of novel type, covid-19 features. Eurasian Chemical Communications, 2020, 2(7), 798-811. Link:

http://www.echemcom.com/article_107 111.html

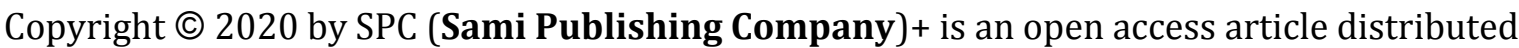
under the Creative Commons Attribution License, which permits unrestricted use, distribution, and reproduction in any medium, provided the original work is properly cited. 